\title{
Analysis Of The Effect Of The Altman Z-Score Method On Financial Distress
}

\author{
Etty Puji lestari $^{1 *}$, Fatia Fatimah ${ }^{2}$, Deni Sunaryo ${ }^{3}$ \\ ${ }^{1,2}$ Universitas Terbuka, Indonesia \\ ${ }^{3}$ Universitas Serang Raya, Indonesia \\ * Corresponding author: \\ Email: ettypl@campus.ut.ac.id
}

\begin{abstract}
.
This study aims to determine the effect of the Altman z-score method on financial distress with the independent variables namely WCTA, RETA, EBITTA, MVETL, and STA on the dependent variable, namely Financial Distress. In manufacturing companies listed on the Indonesia Stock Exchange for the period 2016-2020. Based on the research results that have been described previously, it can be concluded that:In calculating the Altman z-score method in the research year the company is categorized: Safe : CTRA company for 3 years of research, Gray Area : SQBB company for 5 years research, Financial distress: BTEK and AISA companies for 3 years of research. The ratio of Working Capital to Total Assets (WCTA) has a significant effect on Financial Distress. The ratio of Retained Earnings to Total Assets (RETA) has no significant effect on Financial Distress. The ratio of Earnings Before Interest and Taxes to Total Assets (EBITTA) has a significant effect on Financial Distress. The Market Value of Equity to Total Liability (MVETL) ratio has no significant effect on Financial Distress.Ratio of Sales to Total Assets (STA) has a significant effect on Financial Distress. Recommendations for companies to maintain financial ratios (WCTA, RETA, EBTTA, MVETL, and STA) so that companies avoid bankruptcy and can still strive to create improvements to financial ratios (WCTA, EBITTA, and STA) based on research these ratios have a significant effect to financial distress. For researchers to be able to further develop research similar to financial distress such as bankruptcy risk, as well as analysis of financial ratios that can be expanded to do better. In this case, it is not only the types of food and beverage industry companies, but also other types of industrial companies. Subsequent research can use a period of more than five years so that it is expected to be a useful comparison basis for further research.
\end{abstract}

Keywords: WCTA, RETA, EBITTA, MVETL,STA, Altman z-score

\section{INTRODUCTION}

Basically, the purpose of establishing a company is to support efforts to maximize company profits, the company's attitude to increase shareholder wealth and activities to allocate resources efficiently in order to plan long-term profitability. Coal (2011). Manufacturing is one of the pillars driving the Indonesian economy. This sector has always been the main source of employment for the resources in it, but productivity and growth rates in this industrial sector have not been optimal. Indonesia is currently facing a trading environment with increasingly fierce competition, especially the pace of free trade across ASEAN and China. 
This competition is the main focus, making the Indonesian state to be more alert and ready to face the competition. Along with the development of the globalization era, Indonesia is still lacking in scientific development in fields such as technology, effective infrastructure patterns and the slow response to reforms regarding industrial regulations. Efforts are needed to have special attention in order to attract foreign investors as well as domestic investors to give confidence to companies in Indonesia. The growth of the manufacturing industry until 2017 (per the first quarter) is quoted from BPS data. GDP growth to date has not shown a significant contribution. The following is GDP growth:

Table 1.1. 2021 First Quarter GDP Growth

\begin{tabular}{|l|r|r|r|}
\hline \multicolumn{1}{|c|}{ Sectors } & \multicolumn{1}{|c|}{$\mathbf{2 0 1 9}$} & $\mathbf{2 0 2 0}$ & $\mathbf{2 0 2 1 *}$ \\
\hline Manufacturing Industry & 4.33 & 4.29 & 4.21 \\
\hline Agriculture, forestry, \& fishery & 3.77 & 3.25 & 7.12 \\
\hline Wholesale \& retail trade, cars \& motorcycles reparation & 2.59 & 3.93 & 4.77 \\
\hline Construction & 6.36 & 5.22 & 6.26 \\
\hline Mining and Quarying & -3.42 & 1.06 & -0.49 \\
\hline Transportation and warehousing & 6.68 & 7.74 & 7.65 \\
\hline Finance and insurance & 8.59 & 8.90 & 5.73 \\
\hline $\begin{array}{l}\text { Public adm,defense, and compulsory social } \\
\text { security }\end{array}$ & 4.63 & 3.19 & 0.58 \\
\hline Information and communication & 9.69 & 8.87 & 9.10 \\
\hline
\end{tabular}

Source: Central Bureau of Statistics, 2021

From table 1.1 it can be concluded that the manufacturing industry sector experienced a decline every year in 2019 (4.33\%), 2020 (4.29\%) and 2021 (4.21\%) which indicated that the slowing domestic economy, intense business competition was accompanied by low purchasing power of the people so that impact on the company difficult to manage materials to be able to meet its obligations. If a company cannot respond quickly or survive the situation, it is possible that in the long term the company will go bankrupt.Bankruptcy is a condition in which the company enters its final period which is marked by the disappearance of the company's opportunity to earn income in the form of profits to be able to carry out its business sustainability. The symptoms faced when the company went bankrupt was the start of a period in which the company faced financial distress (financial distress). If a company cannot make improvements to the financial difficulties experienced, there are two things that will be 
experienced by a company, namely experiencing bankruptcy or the company will be liquidated.

There have been cases of incompetence in financial management which resulted in companies that were originally listed on the Indonesia Stock Exchange now being delisted. such as the case of PT. Truba Alam Manunggal Engineering Tbk. (TRUB), the Indonesia Stock Exchange carried out a forced delisting on the grounds that the company did not show any effort to improve its business, this was shown by the company not operating and unable to generate income. TRUB was listed on the IDX in 2006 and was officially delisted in September 2018. The Altman Z-Score method is a formula that can be used as a tool to determine the company's financial distress. In the Altman Z-Score method, there are five financial ratios that are thought to affect the company's financial distress, namely Working Capital to Total Assets, Retained Earnings to Total Assets, Earning Before Interest and Taxes to Total Assets, Market Value of Equity to Total Liabilities, and Sales to Total Assets.The ratio of Working Capital to Total Assets is the company's ability to generate net working capital from the total assets it owns. (Hanafi, 2010) A negative net working capital is likely the company will face problems in covering its short-term liabilities due to the unavailability of sufficient current assets. to cover these obligations.Retained Earnings to Total Assets ratio is the company's ability to generate retained earnings from the company's total assets, retained earnings shows how much company income is not paid in the form of dividends to shareholders.

A company that has a negative retained earnings value indicates the company had a bad business year. Bell (2013) in Aprila (2016). The ratio of Earning Before Interest and Taxes to Total Assets is the company's ability to generate profits from company assets, before paying taxes and interest. If this ratio is greater than the average interest rate paid, the Earning Before Interest and Taxes to Total Assets Ratio is the company's ability to generate profits from the company's assets, before paying taxes and interest. If this ratio is greater than the average interest rate paid, it means that the company is able to make more money than the interest on the loan. The ratio of Market Value of Equity to Total Liabilities is the company's ability to meet obligations from the market value of its own capital (common shares). A negative market value of equity indicates that the company is unable to fulfill its obligations properly. (Rahmawati and Hadiprajitno, 2015).Sales to Total Assets ratio is the company's ability to generate sufficient business volume in its total assets, if this ratio is negative, it indicates the company's inability to handle the efficiency of the company's overall assets to generate sales and earn profits.Based on the description above, the researcher conducted a research entitled "Analysis Of The Effect Of The Altman Z-Score Method On Financial Distress"

Based on the formulation of the problem, it can be stated that the hypothesis in this study is as follows: 


\section{Effect of Working Capital To Total Assets (WCTA) on Financial Distress}

The Working Capital To Total Asset (WCTA) ratio is used to determine the company's ability to obtain net working capital in total by looking at the number of assets owned by the company. Working capital is a measure of the company's liquidity level, the higher the liquidity ratio, the lower the company faces financial distress. This is because the company easily pays its short-term obligations. (Hanafi, 2010), if the working capital is negative, it indicates that the company is unable to pay its short-term obligations. This is due to the large value of the company's current debt compared to its current assets, resulting in a negative working capital value, this can push the company into a state of financial distress.Previous research was conducted by Hikmah and Sri Afridola (2019) and Amila Rezky Mufidah (2020) which showed that the WCTA variable had a significant influence on Financial Distress. Based on this description, the hypotheses that can be developed are:

H1: Effect of Working Capital To Total Assets (WCTA) on Financial Distress.

\section{Effect of Retained Earning to Total Assets (RETA) on Financial Distress}

Bell (2013) in Aprylia (2016) Retained Earning to Total Assets (RETA) is a ratio that provides information about the value of total income and losses originating from an investment made by the company and describes the balance of profits obtained. The higher the value of this ratio means that the company has a high profit to finance its assets and pay dividends, so that the probability of financial distress will decrease. Meanwhile, if the RETA value is negative, it means that the company has had a bad business year so that it is in a state of financial distress. In a study conducted by Vira Eneng Asia and Irwan Ch (2015) where the results obtained are that the RETA variable has a significant effect on Financial Distress. Based on this description, the hypotheses that can be developed are:

H2 : Effect of Retained Earning to Total Assets (RETA) on Financial Distress.

\section{Effect of Earning Before Interest and Taxes to Total Assets (EBITTA) Against Financial Distress}

The ratio obtained from Earning Before Interest and Taxes to Total Assets (EBITTA) is used to determine the value of the company's operating profit generated from the total assets owned by the company. The company's operating profit shows the amount of profit earned from operating activities before interest and tax deferrals that must be deferred by the company. This ratio analysis is used to measure whether the assets acquired have been used effectively to generate profits from operating activities. Companies that get a high EBITTA value, the company has carried out effectiveness in production activities, so as to reduce the possibility of the company experiencing financial distress (Hanafi, 2010). In previous research conducted by Eneng Asia and Irwan Ch (2015), Hikmah and Sri Afridola (2019) and Amila Rezky Mufidah (2020) showed that the EBITTA ratio has a significant effect on Financial Distress. Based on this description, the hypotheses that can be developed are: 
H3 : Effect of Earning Before Interest and Taxes to Total Assets (EBITTA) Against Financial Distress.

\section{Effect of Market Value of Equity to Total Liabilities (MVETL) on Financial Distress}

The Market Value of Equity to Total Liabilities (MVETL) ratio is obtained from the number of shares issued by the company multiplied by the total value per share. The results obtained are divided by the total value of debt owned by the company, the results in the form of this ratio can be used as a guide for the company's value in the eyes of the market or can be referred to as market capitalization value. The market value of equity shows the total value of capital owned by the company based on the assessment made by market participants, which describes the size of a company. The larger the size of the company in the eyes of market participants, indicates that the company is not indicated by financial distress. (Rahmawati and Hadiprajitno, 2015).

In research conducted by Amila Rezky Mufidah (2020) shows that the MVETL variable has a significant influence on Financial Distress. Based on this description, the hypotheses that can be developed are:

H4 : Effect of Market Value of Equity to Total Liabilities (MVETL) on Financial Distress.

\section{Effect of Sales to Total Assets (STA) on Financial Distress}

The Sales to Total Asset (STA) ratio is used to show the extent to which the company's strength in creating sales comes from all the company's total assets owned. The sales obtained by the company indicate the company's ability to obtain company profits. The income obtained shows the company's performance in carrying out the company's operational activities related to sales. The more sales the company gets, it can show high efficiency and a good signal not only for the company and investors. So that the company will avoid financial distress conditions (Rahmawati and Hadiprajitno, 2015).In research conducted by Vira Eneng Asia and Irwan Ch (2015) and Hikmah and Sri Afridola (2019) which shows that the STA variable has a significant influence on financial distress. Based on this description, the hypotheses that can be developed are: H5 : Effect of Sales to Total Assets (STA) on Financial Distress.

\section{METHODS}

In the process of collecting this data, the writer uses a descriptive causality method, which is a method for analyzing data by describing or describing the data that has been collected as it is without intending to make general conclusions or generalizations, but aims to examine the relationship and influence that exists between two variables or more. The place of this research was carried out on Manufacturing companies listed on the Indonesia Stock Exchange (IDX) for the 2016-2020 period, the data used was financial report data which was downloaded from the IDX official website, namely www.idx.co.id. The population used in this study is the manufacturing companies listed on the Indonesia Stock Exchange (IDX) for the 2016-2020 period as 
many as 152 companies. The selection of the population depends on the problem to be investigated and the hypothesis to be acknowledged. . The technique used in this research to take samples using purposive sampling technique. The reason for using purposive sampling technique is because not all samples have criteria that are in accordance with what the author has determined.

Therefore, the authors chose a purposive sampling technique by setting certain considerations or criteria that must be met by the samples used in this study. The criteria used as research samples are as follows: Is a manufacturing company listed on the IDX for the 2016-2020 period. Manufacturing companies that were delisted during the 2016-2020 period. Manufacturing companies that are relisting during the 20162020 period. A reliable manufacturing company that publishes its complete financial statements during the 2016-2020 period. Then obtained a sample of 7 companies with 5 years of data observation, so we get a sample of 35 data. The components of the financial statements used are as stated in the operational definition of the variables Working Capital to Total Assets (X1), Retained Earning to Total Assets (X2), Earning Before Interest and Taxes to Total Assets (X3), Market Value of Equity to Total Liabilities (X4), and Sales to Total Assets (X5).

\section{RESULT AND DISCUSSION}

Data analysis is an activity after data from all respondents is collected. Activities in data analysis are grouping data based on variables and types of respondents, mantabulating data based on variables from all respondents, presenting data from each variable studied, performing calculations to answer the problem formulation and performing calculations to test the hypotheses that have been proposed and it can be concluded that data analysis is a the process of simplifying data into a form that is easier to read, understand and interpret. (Sugiyono, 2016). The following is the result of the recapitulation of data collection through the dependent and independent variables using Ms Excel data processing:

Table 4.1.Recapitulation of Altman Z-Score Calculation Results

\begin{tabular}{|c|c|c|c|c|c|c|}
\hline \multirow{2}{*}{ No. } & \multirow{2}{*}{ Company Code } & \multicolumn{5}{|c|}{ Z-Score } \\
\cline { 3 - 7 } & & $\mathbf{2 0 1 6}$ & $\mathbf{2 0 1 7}$ & $\mathbf{2 0 1 8}$ & $\mathbf{2 0 1 9}$ & $\mathbf{2 0 2 0}$ \\
\hline 1. & AISA & 2.243377 & -0.11142 & 2.687586 & -3.35806 & 0.075517 \\
\hline 2. & BTEK & 1.498698 & 0.486776 & 1.031035 & 1.148659 & 1.39579 \\
\hline 3. & CTRA & 2.59724 & 3.734393 & 3.671465 & 2.151143 & 3.512619 \\
\hline 4. & DAJK & 3.18766 & 1.451247 & 2.107485 & 0.871955 & 0.911391 \\
\hline 5. & JPRS & 2.261687 & 2.834428 & 2.497304 & 5.291953 & 7.585969 \\
\hline 6. & SKBM & 4.317453 & 3.13886 & 2.269565 & 2.351573 & 2.076664 \\
\hline 7. & SQBB & 2.428772 & 2.367669 & 2.448823 & 2.497261 & 2.517921 \\
\hline
\end{tabular}

Source: Ms Excel data processing, 2021 
Table 4.2.Category Company Condition

Through Altman Z-Score Calculation

\begin{tabular}{|c|c|c|c|c|c|c|}
\hline No. & \multirow{2}{*}{$\begin{array}{c}\text { Company } \\
\text { Code }\end{array}$} & \multicolumn{5}{|c|}{ Years } \\
\cline { 3 - 7 } & & $\mathbf{2 0 1 6}$ & $\mathbf{2 0 1 7}$ & $\mathbf{2 0 1 8}$ & $\mathbf{2 0 1 9}$ & $\mathbf{2 0 2 0}$ \\
\hline 1. & AISA & Grey Area & FD & Grey Area & FD & FD \\
\hline 2. & BTEK & Grey Area & FD & FD & FD & Grey Area \\
\hline 3. & CTRA & Grey Area & Safe & Safe & Grey Area & Safe \\
\hline 4. & DAJK & Safe & Grey Area & Grey Area & FD & FD \\
\hline 5. & JPRS & Grey Area & Grey Area & Grey Area & Safe & Safe \\
\hline 6. & SKBM & Safe & Safe & Grey Area & Grey Area & Grey Area \\
\hline 7. & SQBB & Grey Area & Grey Area & Grey Area & Grey Area & \multirow{2}{*}{ Grey Area } \\
\hline
\end{tabular}

Source: Ms Excel data processing, 2021

From table 4.2, it can be explained that manufacturing companies on the IDX for the 2016-2020 period have the following categories: In 2016 the AISA company had a z-score of 2.243377 (Grey Area), BTEK had a z-score of 1.498698 (Grey Area), CTRA had a z-score of 2.59724 (Grey Area), DAJK had a z-score of 3.18766 (Safe), JPRS has a z-score of 2.261687 (Grey Area), SKBM has a z-score of 4.317453 (Safe), SQBB has a z-score of 2.428772 (Grey Area). In 2017, AISA companies had a z-score of -0.11142 (Financial Distress), BTEK had a z-score of 0.486776 (Financial Distress), CTRA had a z-score of 3.734393 (Safe), DAJK had a z-score of 1.451247 (Grey Area), JPRS has a z-score of 2.834428 (Grey Area), SKBM has a z-score of 3.13886 (Safe), SQBB has a z-score of 2.367669 (Grey Area). AISA has a z-score of -2.687586 (Grey Area), BTEK has a z-score of 1.031035 (Financial Distress), CTRA has a z-score of 3.671465 (Safe), DAJK has a z-score of 2.107485 (Grey Area ), JPRS has a z-score of 2.497304 (Grey Area), SKBM has a z-score of 2.269565 (Grey Area), SQBB has a zscore of 2.448823 (Grey Area). -score s --3.35806 (Financial Distress), BTEK has Zscore value of 1.148659 (Financial Distress), CTRA has a z-score of 0.871955 (Financial Distress), DAJK has a Z-score of 0.871955 (Financial Distress), JPRS has a Z-score of 5.291953 (Safe), SKBM has a z-score of 2.351573 (Grey Area), SQBB has a Z-score of 2.497261 (Grey Area). In 2020 AISA companies have a z-score of 0.075517 (Financial Distress), BTEK has a z-score of 1.39579 (Financial Distress), CTRA has a Z-score of 3.512619 (Safe), DAJK has a z-score of 0.911391 (Financial Distress), JPRS has a z-score of 7.585969 (Safe), SKBM has a z-score of 2.076664 (Grey Area), SQBB has a z-score of 2.517921 (Grey Area).

\section{Descriptive Statistical Analysis}

Descriptive statistics aim to provide an overview or description of the data seen from the minimum value, maximum value, average value (mean), standard deviation, and variance. The results of the dependent and independent variable data used in this research from data collection and data processing have been used are as follows: 
Table 4.3. Descriptive Statistical Analysis Results

Descriptive Statistics

\begin{tabular}{|l|c|r|r|r|r|r|}
\hline & $\mathrm{N}$ & $\begin{array}{c}\text { Minimu } \\
\mathrm{m}\end{array}$ & $\begin{array}{c}\text { Maximu } \\
\mathrm{m}\end{array}$ & Mean & $\begin{array}{c}\text { Std. } \\
\text { Deviation }\end{array}$ & $\begin{array}{c}\text { Varianc } \\
\mathrm{e}\end{array}$ \\
\hline WCTA & 35 & $-1,8232$ &, 5803 &, 032549 &, 5471183 &, 299 \\
RETA & 35 &,- 0096 & 2,24117 &, 330589 &, 4442621 &, 197 \\
EBITTA & 35 & $-7,9947$ & 3,8268 &, 336166 & 1,662059 & 2,762 \\
MVETL & 35 &, 0026 & 2,9575 &, 954469 &, 7861343 &, 618 \\
STA & 35 &, 0114 & 2,2910 &, 579960 &, 6071438 &, 369 \\
Financial & 35 & $-3,3581$ & 7,5860 & 2,23373 & 1,746169 & 3,049 \\
Distress & 35 & & & & & \\
Valid N (listwise) & & & & & & \\
\hline
\end{tabular}

Source: SPSS 25.0 output, secondary data processed 2021

From the data processing in table 4.5 above using SPSS 25.0, the following results are obtained:

a. Working Capital to Total Assets there are $35(\mathrm{~N})$ results obtained a minimum (lowest value) of -1.8232, namely at AISA companies in 2017. The maximum value (highest value) is 0.5803 at DJAK companies in 2019. Mean (mean value) is 0.032549 .Standard deviation (standard value of standard deviation) is 0.5471183 and Variance is 0.299 .

b. Retained Earning to Total Assets there are $35(\mathrm{~N})$ obtained a minimum (lowest value) of -0.0096 , namely BTEK companies in 2019. The maximum value (highest value) is 2.2417 for AISA companies in 2019. Mean (average value) of 0.330589. The standard deviation (standard deviation value) is 0.4442621 and the variance is 0.197 .

c. Earning Before Interest and Tax to Total Assets, there are $35(\mathrm{~N})$ results obtained with a minimum (lowest value) of -7.9947 , namely the AISA company in 2019. The maximum value (highest value) is 3.8268 at the JPRS company in 2020 . The mean (average value) is 0.336166 . The standard deviation (standard deviation value) is 1.662059 and the variance is 2.762 .

d. Market Value of Equity to Total Liability there are $35(\mathrm{~N})$ obtained a minimum result (lowest value) of 0.0026 , namely for SQBB companies in 2020. The maximum value (highest value) is 2.9575 for CTRA companies in 2018. The mean (average value) is 0.954469 . The standard deviation (standard deviation value) is 0.7861343 and the variance is 0.618 .

e. Sales to Total Assets there are 35 (N) obtained a minimum result (lowest value) of 0.0114 , namely the DJAK company in 2019. The maximum value (highest value) is 2.2910 at the JPRS company in 2020. The mean (value average) of 0.579960 . The standard deviation (standard deviation value) is 0.6071438 and the variance is 0.369 .

f. Financial Distress there are $35(\mathrm{~N})$ results obtained a minimum (lowest value) of -3.3581, namely AISA companies in 2019. The maximum value (highest value) is 
7.5860 in SKBM companies in 2016. Mean (average value) -average) of 2.23373. The standard deviation (standard deviation value) is 1.746169 and the variance is 3.049 .

\section{Multiple Linear Regression Analysis}

To find out the effect of WCTA, RETA, EBITTA, MVETL, and STA ratios on Financial Distress, multiple regression analysis was used to study the relationship between more than two variables. By using the multiple regression analysis method, the test results are shown in table 4.9 below:

Table 4.7. Multiple Linear Test Results

Source: SPSS 25.0 output, secondary data processed 2021

Coefficients $^{\mathbf{a}}$

\begin{tabular}{|c|c|c|c|c|c|c|}
\hline \multicolumn{2}{|c|}{ Model } & \multicolumn{2}{|c|}{ Unstandardized Coefficients } & $\begin{array}{c}\text { Standardized } \\
\text { Coefficients }\end{array}$ & T & Sig. \\
\cline { 3 - 5 } \multicolumn{2}{|c|}{} & B & Std. Error & Beta & & \\
\hline 1 & (Constant) &,- 425 &, 708 & &,- 039 &, 969 \\
& WCTA &, 044 &, 038 &, 760 & 2,754 &, 001 \\
& RETA &, 033 &, 026 &, 151 & 1,464 &, 012 \\
& EBITTA &, 057 &, 042 &, 391 & 6,368 &, 004 \\
& MVETL &, 023 &, 016 &, 453 & 1,509 &, 022 \\
& STA &, 041 &, 032 &, 556 & 3,474 &, 003 \\
\hline
\end{tabular}

a. Dependent Variable: Financial Distress

Source: SPSS 25.0 output, secondary data processed 2021

Based on table 4.9 above, it can be seen the relationship between the independent variable and the dependent variable which can be formulated in the following equation:

$$
\mathrm{Y}=\mathrm{a}+\mathrm{b} 1 \times 1+\mathrm{b} 2 \times 2+\mathrm{b3} \times 3+\mathrm{b} 4 \times 4+\mathrm{b5} \times 5+\mathrm{e}
$$

$\mathrm{Y}=-0,425+0,044 \mathrm{WCTA}+0,033 \mathrm{RETA}+0,057 \mathrm{EBITTA}+0,023 \mathrm{MVETL}+0,041 \mathrm{STA}+\mathrm{e}$

The above equation has the following meaning:

a. The constant value of -0.425 indicates that if the independent variables (WCTA, RETA, EBITTA, MVETL, and STA) have a value of zero, the financial distress variable is worth -0.425 .

b. The regression coefficient for the WCTA variable (X1) of 0.044 indicates that if the other independent variables have a fixed value and the WCTA variable increases by $1 \%$, the financial distress variable will increase by 0.044 .

c. The regression coefficient for the RETA variable (X2) of 0.033 indicates that if the other independent variables have a fixed value and the RETA variable has an increase of $1 \%$, the financial distress variable will increase by 0.033 .

d. The regression coefficient for the EBITTA variable (X3) of 0.057 indicates that if the other independent variables have a fixed value and the EBITTA variable increases by $1 \%$, the financial distress variable will increase by 0.027 . 
e. The regression coefficient for the MVETL variable (X4) of 0.023 indicates that if the other independent variables have a fixed value and the MVETL variable has increased by $1 \%$, the financial distress variable will increase by 0.023 .

f. The regression coefficient for the STA variable (X5) of 0.041 indicates that if the other independent variables have a fixed value and the STA variable has an increase of $1 \%$, the financial distress variable will increase by 0.041 .

g. Standard error (e) indicates the level of intruder error.

\section{Hypothesis Test}

\section{Statistical t test (Partial)}

Ghozali (2011:98), the t statistic test basically shows how far the influence of one explanatory or independent variable individually explains the dependent variables. The following is a summary of the results of the $t$ test in table 4.10 below:

Table 4.8. T-Test Results (Partial)

Coefficients $^{\mathrm{a}}$

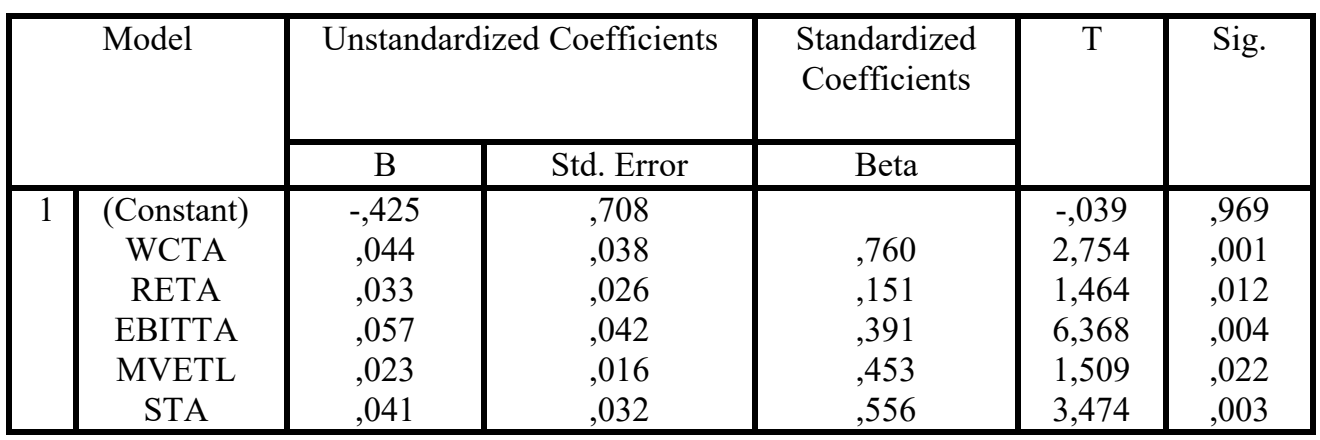

a. Dependent Variable: Financial Distress

Source: SPSS 25.0 output, secondary data processed 2021

Based on table 4.10 above, it can be described as follows:

a. The results of the $t$ test on the WCTA ratio variable (X1) obtained $t$ count $>t$ table of $2.754>2.044$ with a significance value of $0.001<0.05$ thus $\mathrm{H} 1$ is accepted, which means that there is a significant effect of the WCTA ratio (X1) partially on Financial Distress (Y).

b. The results of the $t$ test on the RETA ratio variable (X2) obtained $t$ count $>t$ table of $1.464<2.044$ with a significance value of $0.012>0.05$ thus $\mathrm{H} 2$ is rejected, which means that there is no significant effect of the RETA ratio (X2) partially on Financial Distress (Y).

c. The results of the $t$ test on the EBITTA ratio variable (X3) obtained $t$ count $>t$ table of $6.368>2.044$ with a significance value of $0.004>0.05$ thus $\mathrm{H} 3$ is accepted, which means that there is a significant effect of the EBITTA ratio (X3) partially on Financial Distress ( Y).

d. The results of the $t$ test on the MVETL ratio variable (X4) obtained $t$ count $>t$ table of $1.509>2.044$ with a significance value of $0.022>0.05$, thus $\mathrm{H} 4$ is rejected, 
which means that there is no significant effect of the MVETL ratio (X4) partially on Financial Distress (Y).

e. The results of the $t$ test on the STA ratio variable (X5) obtained $t$ count $>t$ table of $3.474>2.044$ with a significance value of $0.000<0.05$, thus H5 is accepted, which means that there is a significant effect of the STA ratio (X5) partially on Financial Distress (Y).

\section{Coefficient of Determination Test}

The value of the coefficient of determination is indicated by the Adjust $\mathrm{R}$ Square value from the regression model used to determine how far the company's value capability can explain the variation of the independent variables. In addition, this test aims to test the level of closeness of the relationship between the independent variables on the dependent variable. Based on the tests carried out, the following results can be obtained:

Table 4.9. Coefficient of Determination Test Results

Model Summary

\begin{tabular}{|c|c|c|c|c|}
\hline Model & $\mathrm{R}$ & $\mathrm{R}$ Square & Adjusted R Square & $\begin{array}{c}\text { Std. Error of the } \\
\text { Estimate }\end{array}$ \\
\hline 1 &, $622^{\mathrm{a}}$ &, 635 &, 562 &, 68841 \\
\hline
\end{tabular}

a.Predictors: (Constant), WCTA, RETA, EBITTA, MVETL, STA

b.Dependent Variable: Financial Distress

Source: SPSS 25.0 output, secondary data processed 2021

Based on table 4.11 above, Based on the table above, an $\mathrm{R}$ value of 0.622 is obtained so that it can be seen that the Adjusted R-Square value of 0.562 This means that the independent variables, namely WCTA, RETA, EBITTA, MVETL, and STA are able to explain or explain $56.2 \%$ to financial distress. While $43.8 \%$ is explained by other factors not examined in this study.

\section{Discussion}

\section{Effect of WCTA on Financial Distress}

Based on the results of the study, it can be seen that the Working Capital to Total Assets (WCTA) variable has a significant influence on the potential for financial distress in manufacturing companies listed on the Indonesia Stock Exchange (IDX) for the 2016-2020 period. It can be seen from the results of testing the WCTA variable (X1) on the potential financial distress variable (Y), the value of $t$ count $>t$ table is $2.754>2.044$ with a significance value of $0.001<0.05$. This means that WCTA has a significant effect on the company's financial distress potential. Thus H1 which states that WCTA has a significant effect on financial distress is accepted. Based on the results of the study, there is a significant influence between the WCTA variables on financial distress.

This is because the increase in the value of WCTA in the company indicates that the greater the level of protection for short-term liabilities in the company, and the 
greater the certainty that short-term debt will be repaid on time, which means the company can manage its obligations properly and the impact on the company is avoided from financial distress. The results of this study are in line with research conducted by Hikmah and Sri Afridola (2019) and Amila Rezky Mufidah, et al (2021) which stated that WCTA had a significant effect on the potential for financial distress.

\section{Effect of RETA on Financial Distress}

Based on the results of the study, it can be seen that the Retained Earnings to Total Asset (RETA) variable has a significant effect on financial distress in manufacturing companies listed on the Indonesia Stock Exchange (IDX) for the 20162020 period. It can be seen from the results of testing the RETA (X2) variable on the potential financial distress variable $(\mathrm{Y})$, the value of $\mathrm{t}$ count $>\mathrm{t}$ table is $1.464>2.044$ with a significance value of $0.012>0.05$. This means that RETA has no significant effect on the company's potential financial distress.

Thus H2 which states that RETA has a significant effect on financial distress is rejected. Based on the results of the study, there is no significant effect between the RETA variable on financial distress. This is because the high and low RETA cannot determine the company's level of financial distress. RETA does not guarantee that financial distress will increase when the RETA ratio is low, which means the company lacks capital to pay debts and dividends. However, if the results of the measurement ratio are high, it does not mean that the company's condition is good. This can happen because cash is not managed as well as possible. The results of this study are not in line with research conducted by Vira Eneng Asia and Irwan Ch (2017) which states that RETA has a significant effect on the potential for financial distress.

\section{The Effect of EBITTA on Financial Distress}

Based on the results of the study, it can be seen that the Earnings Before Interest and Tax to Total Asset (EBITTA) variable has a significant influence on financial distress in manufacturing companies listed on the Indonesia Stock Exchange (IDX) for the 2016-2020 period. It can be seen from the results of testing the EBITTA variable $(\mathrm{X} 3)$ on the potential financial distress variable $(\mathrm{Y})$, the value of $\mathrm{t}$ count $>\mathrm{t}$ table is $6.368>2.044$ with a significance value of $0.004<0.05$. This means that EBITTA has a significant effect on the company's financial distress potential. Thus H3 which states that EBITTA has a significant effect on financial distress is accepted. Based on the results of the study, there is a significant influence between the EBITTA variable on financial distress.

This is because companies that get high EBITTA values indicate that the company has carried out effectiveness in production activities, so as to reduce the possibility of the company experiencing financial difficulties. The resulting high profits support greater confidence for investors which can support rising share prices. Based on signaling theory, it explains that high profits obtained by the company provide good prospects in the future. This can describe a sensitive signal response for investors to earnings. The results of this study are in line with research conducted by 
Vira Eneng Asia and Irwan Ch (2017), Hikmah and Sri Afridola (2019) and Amila Rezky Mufidah, et al (2021) which state that EBITTA has a significant effect on financial distress.

\section{The Effect of MVETL on Financial Distress}

Based on the results of the study, it can be seen that the Market Value Equity to Total Liabilities (MVETL) variable has a significant influence on financial distress in manufacturing companies listed on the Indonesia Stock Exchange (IDX) for the 2016-2020 period. It can be seen from the results of testing the MVETL variable (X4) on the potential financial distress variable $(\mathrm{Y})$. The value of $\mathrm{t}$ count $>\mathrm{t}$ table is $1.509>$ 2.044 with a significance value of $0.022>0.05$. This means that MVETL has no significant effect on the company's potential financial distress.

Thus H4 which states that MVETL has a significant effect on financial distress is rejected. Based on the results of the study, there is no significant effect between the MVETL variable on financial distress which indicates that the company is unable to fulfill its obligations from the market value of its capital so that it can reduce the confidence of external parties such as investors to invest in the company, this problem can result in financial difficulties in the company. companies and companies experiencing very large financial distress conditions. The results of this study are not in line with research conducted by Amila Rezky Mufidah, et al (2021) which states that MVETL has no significant effect on financial distress.

\section{Effect of STA on Financial Distress}

Based on the results of the study, it can be seen that the Sales to Total Assets (STA) variable has a significant influence on financial distress in manufacturing companies listed on the Indonesia Stock Exchange (IDX) for the 2016-2020 period. It can be seen from the results of testing the STA variable (X5) on the potential financial distress variable $(Y)$, the value of $t$ count $>t$ table is $3.474>2.044$ with a significance value of $0.000<0.05$. This means that STA has a significant effect on the company's financial distress potential. . Thus, H5 which states that STA has a significant effect on financial distress is accepted. Based on the results of the study, there is a significant influence between the STA variables on financial distress.

This is because the STA Ratio explains that the more sales a company gets, it can show high efficiency and a good signal not only for the company, but also for investors. This is in line with signaling theory which shows that profitability is measured by revenue and sales which give a signal to investors. Namely, the higher the income generated, the greater the increase in investor confidence, with this making it easier for management to take capital in the form of shares. This applies vice versa if the company experiences a decrease in sales which results in a decrease in the value of profits which can encourage the company to be in financial distress. The results of this study are in line with research conducted by Vira Eneng Asia and Irwan Ch (2017) and Hikmah and Sri Afridola (2019) which stated that STA had a significant effect on financial distress. 


\section{CONCLUSION}

This study aims to determine the effect of the Altman z-score method on financial distress with the independent variables namely WCTA, RETA, EBITTA, MVETL, and STA on the dependent variable, namely Financial Distress. In manufacturing companies listed on the Indonesia Stock Exchange for the period 20142018. Based on the research results that have been described previously, it can be concluded that:In calculating the Altman z-score method in the research year the company is categorized: Safe : CTRA company for 3 years of research, Gray Area : SQBB company for 5 years research, Financial distress: BTEK and AISA companies for 3 years of research. The ratio of Working Capital to Total Assets (WCTA) has a significant effect on Financial Distress. The ratio of Retained Earnings to Total Assets (RETA) has no significant effect on Financial Distress. The ratio of Earnings Before Interest and Taxes to Total Assets (EBITTA) has a significant effect on Financial Distress. The Market Value of Equity to Total Liability (MVETL) ratio has no significant effect on Financial Distress.Ratio of Sales to Total Assets (STA) has a significant effect on Financial Distress.

\section{ACKNOWLEDGMENTS}

The authors are grateful to The Chancellor and the leadership at Terbuka University, Banten Indonesia

\section{REFERENCES}

[1] Altman Edward. 1968. Financial Ratios, Discriminant Analysis And The Prediction Of Corporate Bankrupty. The Journal of Finance, VOL. XXIII, September, 589-609.

[2] Andre, Orina. 2013. Pengaruh Profitabilitas, Likuiditas, Dan Leverage Dalam Memprediksi Financial Distress (Studi Empiris Pada Perusahaan Aneka Industri Yang Terdaftar Di BEI). Padang : Program Studi Akuntansi Fakultas Ekonomi Universitas Negeri Padang.

[3] Altman Edward 1993. Corporate Financial Distress \& Bankruptcy A Complete Guide To Predicting \& Avoiding Distress And Profiting From Bankruptcy Second Edition. Canada. John Willey \& Sons. Inc

[4] Ardiyanto, F., dan Prasetyo. 2011 Prediksi Rasio Keunagn Terhadap Kondisi Financial Distress Perusahaan Manufaktur Yang Terdaftar Di BEI. Dipublikasikan Semarang: Fakultas Ekonomi Universitas Diponegoro.

[4] Ahmed Adeshina Babatunde, et al. 2017. The Effectiveness Of Altman's Z-Score In Predicting Bankruptcy Of Quoted Manufacturing Companies In Nigeria. European Journal of Business, Economics and Accountancy Vol. 5, No. 5. ISSN : 2056-6018.

[5] Brigham, E. F., \& Houston, J. F. 2011. Fundamentals of financial management. Cengage Learning.

[6] Ch. A. Sondakh, et al. 2014. Analisis Potensi Kebangkrutan Dengan Menggunakan Metode Altman Zscore, Springate dan Zmijewski Pada Industri Perdagangan Ritel Yang Terdaftar Di BEI Periode 2009-2013. Jurnal EMBA Vol.2 No.4 ISSN : 23031174. 
[7] Ditiro Alam Ben, et al. 2014. Analisis Metode Springate (S-Score) Sebagai Alat Untuk Memprediksi Kebangkrutan Perusahaan (Studi Pada Perusahaan Property dan Real Estate yang listing di BEI Tahun 2011-2013. Jurnal Administrasi Bisnis (JAB) Vol. 21 No. 1.

[8] Fachrudin, K. A. 2008. Kesulitan Keuangan Perusahaan dan Personal. Medan: USU Press.

[9] Fatmawati, Amelia. 2017. Faktor-Faktor Yang Memperngaruhi Financial Distress (Studi Pada Perusahaan Manufaktur Di BEI. Jurnal Ilmu Dan Riset). Nomor 10, 2360-0585.

[10] Ghozali, I. (2011). Partial Least Squares Konsep, Teknik dan Aplikasi Menggunakan Program Smartpls 3.0. Yogyakarta: Badan Penerbit Universitas Diponegoro.

[11] Hanafi, M. Mamdu. 2010. Manajemen Keuangan. Ed 1. Yogyakarta: BPFE.

[12] Hikmah dan Sri Afridola. 2019. Pengaruh Rasio Keuangan Altman Z-Score Terhadap Financial Distress Pada Pt Citra Tubindo, Tbk. Jurnal Insitusi Politeknik Ganesha Medan Vol. 2 No. 1. e-ISSN : 2599-1787 - P-ISSN : 2599-17791.

[13] Ikatan Akuntan Indonesia. 2016. Standar Akuntansi Keuangan Revisi. Jakarta: Salemba Empat.

[14] Iqbal dan Wisni. 2012. Prediksi Financial Distress Dengan Menggunakan Altman ZScore Modifikasi.

[15] Kariyoto. 2018. Manajemen Keuangan : Konsep Dan Implementasi. Malang: UB Press.

[16] Kasmir. 2014. Analisis Laporan Keuangan. Jakarta : Rajawali Pers.

[17] Katarina dan Sri. 2017. Analisis Penilaian Financial Distress Menggunakan Model Altman (Z Score) Pada Perusahaan Farmasi Yang Terdaftar Di BEI Periode 20132015. Jurnal Akuntansi, Ekonomi dan Manajemen Bisnis Vol. 5 No. 1. 55-71 E-ISSN 2548-9836.

[18] Jogiyanto, H. M. (2013). Sistem Teknologi Informasi Bisnis: Pendekatan Strategis. Jakarta: Salemba Empat.

[19] Mamduh M. Hanafi. 2009. Analisis Laporan Keuangan, Edisi ke-4, UPP. Yogyakarta: STIM YKPN.

[20] Mar'ati dan Rustam. 2014. Implementasi Penggunaan Metode Altman (Z-Score) Untuk Menganalisis Estimasi Kebangkrutan Studi pada PT Bursa Efek Indonesia Periode 2011-2013. Administrasi Bisnis (JAB) Vol. 10 No. 1.

[21] Muhammad Akhyar Adnan, Eha kurniasih. 2000. Anaisis Tingkat Kesehatan Perusahaan Untuk Memprediksi Potensi Kebangkrutan Dengan Pendekatan Altman (Kasus Pada 10 Perusahaan Di Indonesia). JAAI Vol 4, No.2, hal. 131- 151.

[22] Munawir, Analisis Laporan Keuangan. 2000. Jogjakarta: Liberty.

[23] Nikke Yusnita, 2019. Analisis Laporan Keuangan. Fakultas Ekonomi dan Bisnis Universitas Serang Raya.

[24] Pramuditya, A.Y. 2014. Analisis Pengaruh Penerapan Mekanisme Corporate Governance terhadap Kemungkinan Perusahaan Mengalami Kondisi Financial Distress (studi empiris pada Perusahaan manufaktur yang terdaftar di Bursa Efek Indonesia tahun 2010 - 2012). Universitas Diponegoro

[25] Rahmawati, Aryani I. E., Hadiprajitno P. B. (2015). Analisis Rasio Keuangan terhadap Kondisi Financial Distress pada Perusahaan Manufaktur yang Terdaftar di Bursa Efek Indonesia Tahun 2008-2013. Diponegoro Journal of Accounting. 4 (2): 1-11. 
[26] Reno Thanjaya. 2016. Analisa Kegunaan Model Altman, Grover Dan Zmijewski Untuk Memprediksi Financial Distress.

[27] Savitri, Dita, W. Analisis Prediktor Kebankrutan terbaik menggunakan Model Altman, Springate, dan Zmijewski pada Perusahaan Delisting dari BEI tahun 2012. Jurnal Eproceeding of Management Vol.1 (No.3) h.1- Universitas Telkom 2014.

[28] Sugiyono, 2014. Metode Penelitian Kuantitatif dan Kualitatif dan $R \&$ D . Bandung: Alfabeta.

[29] Tom Ongesa Nyamboga, et.al. 2014. Determinants of Corporate Financial Distress: Case of Non Financial Firms Listed in the Nairobi Securities Exchange. Research Journal of Finance and Accounting www.iiste.org ISSN 2222-1697 (Paper) ISSN 22222847 (Online) Vol.5, No.12.

[30] Vira Eneng Asia dan Irwan Ch. 2015. Pengaruh Rasio Keuangan Terhadap Prediksi Kebangkrutan Altman Zscore Industri Makanan Dan Minuman Yang Terdaftar Di Bursa Efek Indonesia Tahun 2009-2011. Jurnal Visionida Vol. 1 No. 1.

[31] Zakiyyah et.al,. 2014. Analisis Penggunaan Model Zmirewski (X-Score) Dan Altman (Z-Score) Untuk Mempreksi Potensi Kebangkrutan. Journal Administrasi Bisnis. Vol 12 no 12. Universitas Brawijaya. 